\section{Future of Technical Colleges}

Is recent educational discussions changes have been suggested in the relative status of university and technical institutions. Some of the suggestions have taken form and substance in various reports, for example that of the Institute of Physics dealing with the education and training of physicists. The policies suggested have so fundamental a bearing on the future of technical colleges of the first rank that they should be made as public as possible before any irreparably damaging step is taken. One notes, for example, that the report referred to hopes to "relieve the Technical Colleges of the necessity of preparing students for External University Degrees". The elastic term technieal college includes institutions of every type from the lowest to the highest rank, and the subsequent discussion and suggestions refer to those technical colleges of the highest.rank, which would suffer most greatly by this step. Such a "relief" would, in the opinion of a large number of those interested in the growth of technical education, disable and de-rank big technical institutions which have rendered sterling service to technology, and have striven hard, often with little national or local interest, to become institutes of technology of university rank and status.

Whatever policies in technical education the postwar period ushers in, the standard of highest rank technical colleges, with their fine record of service and close attention to the needs of industry, should be safeguarded more than ever in a world where technology seems destined to play an ever-increasing part. Even major technical colleges have suffered too much in the past from being maintained as subordinate institutions. From this position, the only means of escape has been to become university colleges, and in the process of transition many purely technical departments have become attached to universities, the functions of which are more normally academic. This process of accretion of technical departments to universities could not but be accelerated by the move suggested by the Committee, denying as it does the right of the technical college to give the highest training to the young technologist. The best general training which can be devised is along the lines of a university degree course in technical subjects, such as chemistry, physics, engineering, pharmacy, commerce, chemical engineering, metallurgy, textile technology and the like, and no such crippling handicap should be imposed on big technical colleges and their students as denying the former the right to their proper function, and the latter their right to the highest standard of tuition there.

In our opinion, the correct development of technical education does not lie along lines of transference of all higher flights of technology to the universities. Instead there should be in Great Britain a group of institutes of technology, properly equipped and adequately financed, of definite equality in status to the universities. Such institutions exist in the Continent of Europe and in the United States. No one there, even from the universities, would think of de-ranking them. They send out a flow of graduates who take the highest industrial posts ; they contribute a steady stream of fundamental research; their professors are world-famous. The Iustre of the Zurich Polytechnic, or the Massachusetts Institute of Technology, to name two of many equally splendid institutions, is as bright as that of any contemporary university. It is difficult, with the totally different example and experience of so many other countries before one, to contemplate such a retrograde step as that recommended by the Report, which leaves the technical colleges, irrespective of their standing, only minor courses of National Certificate charater, and only second-rate students.

$\begin{array}{cl}\text { Technical College, } & \text { R. M. Barker. } \\ \text { Bradford. } & \text { J. P. ANDREws. }\end{array}$

June 24.

\section{Microchemical Apparatus}

The microchemical apparatus used in Great Britain before 1939 was, in the main, imported from Austria, where Prof. Pregl and his co-workers instructed com. petent apparatus makers such as Paul Haack, and approved for use in the exacting microchemical technique the products they manufactured.

Chemists in Great Britain have been slow to adopt micro methods. We believe this to be due to a number of causes. (a) The lack of an active organiza. tion to arrange meetings and demonstrations and to develop an interest in the subject. The Microchemical Club did something towards this end, but it is now defunct ${ }^{1}$. (b) The foreign apparatus was imported and could not, therefore, be described as being 'freely' available. The spread of a new science is greatly encouraged if the apparatus for it is easy to obtain. (c) Arising out of $(a)$ and $(b)$, the diversity of views among workers and their failure to agree how microchemical apparatus should be constructed. It is true that text-books describe minutely some of the special points to be observed during manufacture; but many features are not clearly specified, either by illustration or by literary description. Glassblowing is an art; not a precise engineering operation; tolerances have to be allowed and the closer the tolerances the greater the difficulty in manufacture and hence the greater the cost.

Until, therefore, microchemists can band them. selves together for their common interest and agree what they want and how it should be made, dis. satisfaction with British-made apparatus will continue to be expressed by some of them. In the United States a start has been made and some approved specifications have already been published ${ }^{2}$.

In our view the bodies in Great Britain primarily interested should appoint a panel to draw up specifications acceptable to both users and manufacturers. These might be the British Standards Institution, the Society of Public Analysts and Other Analytical Chemists, the Chemical Society, the Royal Institute of Chemistry, various Government Departments and others concerned, and work here should be linked up with what is being done in the United States.

British manufacturers are ready and willing to give their full co-operation in any project for the standardization of apparatus for this growing science. This Association would welcome collaboration with any microchemical organization in the examination, from the manufacturing point of view, of any draft specifications.

Technical Committee,

Stanley J. Davies.

British Laboratory Ware Association, Ltd., 73 Basinghall Street, London, E.C.2.

1 Belcher, J. Soc. Chem. Ind., 62, 158 (1943).

${ }^{2}$ Ind. and Eng. Chem., Anal. Edn., 13, 454 (1941) ; 15, 230 (1943). 